\title{
Widespread plant species: natives versus aliens in our changing world
}

\author{
Thomas J. Stohlgren • Petr Pyšek • John Kartesz • Misako Nishino • \\ Aníbal Pauchard · Marten Winter · Joan Pino • David M. Richardson • \\ John R. U. Wilson • Brad R. Murray • Megan L. Phillips • Li Ming-yang • \\ Laura Celesti-Grapow $\cdot$ Xavier Font
}

Received: 18 January 2011/Accepted: 9 May 2011/Published online: 21 May 2011

(C) Springer Science+Business Media B.V.(outside the USA) 2011

\begin{abstract}
Estimates of the level of invasion for a region are traditionally based on relative numbers of native and alien species. However, alien species differ dramatically in the size of their invasive ranges. Here we present the first study to quantify the level of invasion for several regions of the world in terms of
\end{abstract}

Electronic supplementary material The online version of this article (doi:10.1007/s10530-011-0024-9) contains supplementary material, which is available to authorized users.

T. J. Stohlgren $(\bowtie)$

National Institute of Invasive Species Science,

US Geological Survey, Fort Collins Science Center,

Fort Collins, CO 80526, USA

e-mail: stohlgrent@usgs.gov

P. Pyšek

Institute of Botany, Academy of Sciences of the Czech Republic Průhonice, Charles University Prague, Prague, Czech Republic

\section{P. Pyšek}

Department of Ecology, Faculty of Science, Charles University Prague, Prague, Czech Republic

\section{J. Kartesz $\cdot$ M. Nishino}

Biota of North America Program, 9319 Bracken Lane, Chapel Hill, NC 27516, USA

\section{A. Pauchard}

Laboratorio de Invasiones Biológicas, Facultad de Ciencias Forestales, Universidad de Concepción \& Institute for Ecology and Biodiversity (IEB), Casilla 160-C, Concepción, Chile the most widely distributed plant species (natives vs. aliens). Aliens accounted for $51.3 \%$ of the 120 most widely distributed plant species in North America, 43.3\% in New South Wales (Australia), 34.2\% in Chile, $29.7 \%$ in Argentina, and 22.5\% in the Republic of South Africa. However, Europe had only $1 \%$ of alien species among the most widespread species of the flora. Across regions, alien species relative to native species were either as well-distributed (10 comparisons) or more widely distributed

M. Winter

Department of Community Ecology, Helmholtz Centre for Environmental Research-UFZ, Theodor-Lieser-Str. 4, 06120 Halle (Saale), Germany

J. Pino

Center for Ecological Research and Forestry

Applications(CREAF), Autonomous University of

Barcelona, 08193 Bellaterra, Spain

D. M. Richardson - J. R. U. Wilson

Department of Botany and Zoology, Centre for Invasion Biology (CIB), Stellenbosch University, Private Bag X1, Matieland 7602, South Africa

J. R. U. Wilson

South African National Biodiversity Institute (SANBI), Kirstenbosch National Botanical Gardens, Claremont, South Africa 
(5 comparisons). These striking patterns highlight the profound contribution that widespread invasive alien plants make to floristic dominance patterns across different regions. Many of the most widespread species are alien plants, and, in particular, Europe and Asia appear as major contributors to the homogenization of the floras in the Americas. We recommend that spatial extent of invasion should be explicitly incorporated in assessments of invasibility, globalization, and risk assessments.

Keywords Alien plants - Biotic homogenization China · Europe · Globalization · North America . Plant invasions · South Africa · South America . Species distributions

\section{Introduction}

In recent millennia, increasing human trade has been bridging the continents, thus somewhat restoring the old supercontinent Pangaea (Condie 1989; Mack 2001). In fact, moving plant species around the globe for "food, fuel, forage, and medicine" is said to be one of the defining characteristics of the human species (Mack 2001). With exponentially increasing exploration, trade, and transportation, the intentional delivery of plant species is breaking geographic barriers at unprecedented rates, bringing many hitchhiking seeds, propagules, and pathogens along with them (Richardson et al. 2000; Mack 2001; Whinam et al. 2005; Hulme et al. 2008), in a manner unlike any previous dispersal events (Wilson et al. 2009).

\footnotetext{
B. R. Murray · M. L. Phillips

Department of Environmental Sciences, Plant Functional Biology and Climate Change Cluster, University of Technology Sydney, P.O. Box 123, Broadway, NSW 2007, Australia

\section{Ming-yang}

College of Forest Resources and Environment, Nanjing Forestry University, Nanjing 210037, Jiangsu, China

L. Celesti-Grapow

Dipartimento di Biologia Vegetale, Università La Sapienza, Piazzale Aldo Moro, 5, 00185 Rome, Italy

X. Font

Plant Biology Department, University of Barcelona, Diagonal 645, 08028 Barcelona, Spain
}

We divided the paper into three parts. First, we provide a brief overview of the potential "homogenization" of the species around the globe, based largely on assessments of alien species numbers (or fraction of floras). Second, we provide the first quantitative analysis of alien and native species distributions, focusing on recently compiled datasets on widely distributed plant species to demonstrate how broadly biotic homogenization is occurring. Third, we discuss our major findings with the focus on the history of "globalization" as the significant cultural and economic drivers of environmental change.

\section{Homogenization of biota}

The ongoing spread of alien species has been reported as one of the major causes of biotic homogenization (Sax et al. 2002; Davis 2003) across the globe. Homogenization is defined as the increasing similarity of species composition due to the concurrent extirpation of rare or even unique native species, and the increase of common, widespread alien species (definition adapted from McKinney and Lockwood 1999), although it is worth noting that the combined effects of invasions and extirpations/extinctions can have no effect on or actually increase the compositional turnover (i.e., beta-diversity) of species (Olden and Poff 2003; Cassey et al. 2006). Generally, however, local species assemblages have become less distinct (McKinney and Lockwood 2001; Olden and Poff 2003; Pino et al. 2009; Winter et al. 2009). And, in most regions of the world, invasions exceed extirpations thereby increasing species richness ( $\mathrm{Sax}$ et al. 2002; Stohlgren et al. 2008).

There are two major concerns with such analyses. First, most studies focus on continental or smaller scales (e.g. for plants: Rejmánek 2000; McKinney and Lockwood 2001; Rooney et al. 2004; Qian and Ricklefs 2006; Castro and Jaksic 2008, Winter et al. 2008; fishes: Olden and Poff 2003; Leprieur et al. 2008; birds: La Sorte and Boecklen 2005; Van Turnhout et al. 2007), while few studies have looked at intercontinental or global scales (c.f. La Sorte et al. 2007; Winter et al. 2010, Kueffer et al. 2010). Second, biotic homogenization has been traditionally analysed using classical similarity indices based on species numbers (e.g. Olden and Rooney 2006; Pino et al. 2009). However, using species frequencies and abundances might contribute to a more complete view to 
biotic homogenization than species richness, as these measures are informative of species dominance in habitats and regions and therefore likely to result in impacts on ecosystem function (e.g. McKinney and Lockwood 2005; McKinney and La Sorte 2007; Lambdon et al. 2008a).

\section{Alien and native species distributions}

Studies comparing the degree of invasions of regions are similar to globalization studies, i.e., traditionally based on relative numbers of native and alien species (e.g. Lonsdale 1999; Pyšek et al. 2004b). Yet, how widespread alien species are is an important additional consideration and arguably more tightly linked to the likely impacts. Moreover, this raises the question-are alien species distributions fundamentally different from those of native species, or are they simply adding to existing abundance-occupancy patterns?

Native species have likely had far more evolutionary time than alien species to migrate, adapt, and expand their distributions (i.e. to sample ecological niches in their respective regions). While, as a general rule, species in their native range do not fill their fundamental niches (Peterson 2001), the process of range expansion has rarely been completed for most plant invasions (e.g. Wilson et al. 2007; Williamson et al. 2009). However, if alien plant species are equally as widely distributed as native species in a much shorter time, this suggests alien species may have more highly efficient establishment and dispersal mechanisms. If true, there would still be a principle difference in that these processes would have been operating much faster on alien rather than in native species, possibly reflecting extraordinary dispersal abilities of aliens and their high competitiveness in colonizing new habitats, for reasons believed to determine the success of alien invasive species (Pyšek and Richardson 2007; Pyšek et al. 2009). Quantifying species distributions also is important because widely distributed species generally are less prone to environmental stochasticity and extinction (Jablonski 1989). If aliens were more widely spread than natives, this would indicate that part of the invasion process is operating differently to background distributional range expansion and occupancy (e.g., the alien species are different, the environment has changed to favour aliens, or human assisted dispersal enables aliens to gain wider distributions). If certain aliens have narrower distributions than natives, then this could indicate that aliens may not have reached their distributional limits, or for various reasons, these aliens are less capable of widespread invasions.

To obtain insight into this issue, we compiled data from available datasets and explored three subhypotheses related to widely distributed species:

The fraction of widely distributed plant species that is alien, i.e., introduced from other biogeographical regions, is similar among regions

This is unknown at present. From the onset, we are concerned only with the most widely distributed plant species in each region, because we are less concerned, from a homogenization perspective, about high numbers or fractions of alien species with restricted distributions. Since trade is a two-way street, we might expect similar exposures or opportunities for invasion and homogenization among regions. However, trade imbalance and product differences may have important consequences. For example, many more horticultural products are exported from Asia than are imported (Reichard and White 2001). Europe has been cast as a donor of plant species to North America based on a few small case studies (Jäger 1988; di Castri 1989). Trade imbalance does not make a region a poor donor or receptor, but it may contribute to the pattern. Some regions might be great donors of widely spreading species, but poor receptors of alien species. Similarly some regions, e.g. Australia, have only been connected recently, and as such, one might expect invasive plants to be less widespread, i.e., less time available for invasions.

The alien plant species on regional/continental lists of the most widely distributed plant species are as widely distributed as native plant species

If the range size of alien species is equal or greater than that of native plant species, then native and alien species may behave in the same way to the environment (Thompson et al. 1995), indicating that global homogenization may be well on the way. If ranges of the most widely distributed alien species were, on average, still smaller than native species' ranges, we may be early in the global invasion process, or native species may be maintaining a distributional advantage. 
Widely distributed native or alien species around the globe tend to come from particular plant families or groups

Finding the same species, genera, and families on the lists of widely spread alien plant species is important in understanding the traits of highly invasive species, and such knowledge may be used prevention efforts.

\section{Methods}

We gathered information on the distributions of the 120 most widely distributed vascular plant species in each region (Table 1; Fig. 1) based upon their frequency (occurrences) in defined subregions (ecological zones or administrative units) or grid cells (typically $10 \mathrm{~km} \times 10 \mathrm{~km}$, or $11 \times 12 \mathrm{~km}$; Schönfelder 1999). Unfortunately, for China, only preliminary data listing 109 species (those being woody) were available. Species were characterized as "native" or "alien", the latter being plant species not native to the biogeographical region or country, having arrived by means of human activities (Richardson et al. 2000). In Europe, there is often a distinction made between introduced plants ("neophytes" arriving after $1500 \mathrm{AD}$ or "archeophytes" arriving prior to 1500 AD; see Pyšek et al. 2004a), but for simplicity, we lumped these here as "aliens." The initial cutoff point of 120 species was arbitrary, but based largely upon our general knowledge of plant frequency distributions (Stohlgren 2007, p. 7), where plant frequency distributions level off to low numbers of occurrences.

Table 1 Regions, subregions, area, and data sources used in this paper

\begin{tabular}{|c|c|c|}
\hline Regions & Area $\left(\mathrm{km}^{2}\right)$ Subregions & Data source \\
\hline Argentina & $\begin{array}{l}2,766,890 \mathrm{~km}^{2} \\
\text { (24 bioregional subregions) }\end{array}$ & Zuloaga and Morrone (1996) \\
\hline Chile & $\begin{array}{l}756,950 \mathrm{~km}^{2} \\
(13 \text { bioregions })\end{array}$ & http://www.darwin.edu.ar/Proyectos/FloraArgentina/FA.asp \\
\hline Europe & $\begin{array}{l}10,500,000 \mathrm{~km}^{2} \\
(23 \text { countries })\end{array}$ & $\begin{array}{l}\text { Alien species: DAISIE (2009); (www.europe-aliens.org) } \\
\text { Native species: Winter et al. (2010) }\end{array}$ \\
\hline Catalonia, Spain & $\begin{array}{l}32,000 \mathrm{~km}^{2} \\
(319 \text { grid cells; } 10 \times 10 \mathrm{~km})\end{array}$ & $\begin{array}{l}\text { Pino et al. (2009); } \\
\text { (http://biodiver.bio.ub.es/biocat/homepage.html) }\end{array}$ \\
\hline Czech Republic & $\begin{array}{l}78,000 \mathrm{~km}^{2} \\
(679 \text { grid cells; } 11 \times 12 \mathrm{~km})\end{array}$ & Pyšek et al. (2002) \\
\hline Great Britain and Ireland & $\begin{array}{l}315,134 \mathrm{~km}^{2} \\
(3,751 \text { grid cells; } 10 \times 10 \mathrm{~km})\end{array}$ & Preston et al. (2002) \\
\hline New South Wales, Australia & $\begin{array}{l}809,444 \mathrm{~km}^{2} \\
(13 \text { bioregions })\end{array}$ & http://plantnet.rbgsyd.nsw.gov.au \\
\hline North America (North of Mexico) & $\begin{array}{l}24,500,000 \mathrm{~km}^{2} \\
\text { (64 states or provinces) }\end{array}$ & Kartesz (2010) \\
\hline California & $\begin{array}{l}410,000 \mathrm{~km}^{2} \\
(58 \text { counties })\end{array}$ & Kartesz (2010) \\
\hline Florida & $\begin{array}{l}170,451 \mathrm{~km}^{2} \\
(67 \text { counties })\end{array}$ & Kartesz (2010) \\
\hline Texas & $\begin{array}{l}696,241 \mathrm{~km}^{2} \\
(254 \text { counties })\end{array}$ & Kartesz (2010) \\
\hline People's Republic of China & $\begin{array}{l}9,600,000 \mathrm{~km}^{2} \\
\text { (18 biogeographical regions }\end{array}$ & Zhengyi (2003) \\
\hline Republic of South Africa & $\begin{array}{l}1,219,912 \mathrm{~km}^{2} \\
(1,926 \text { quarter degree grid cells })\end{array}$ & $\begin{array}{l}\text { Alien species: Henderson (1998); (www.agis.agric.za/wip) } \\
\text { Native species: Germishuizen and Meyer (2003); ( } \\
\text { www.sibis.sanbi.org) }\end{array}$ \\
\hline
\end{tabular}




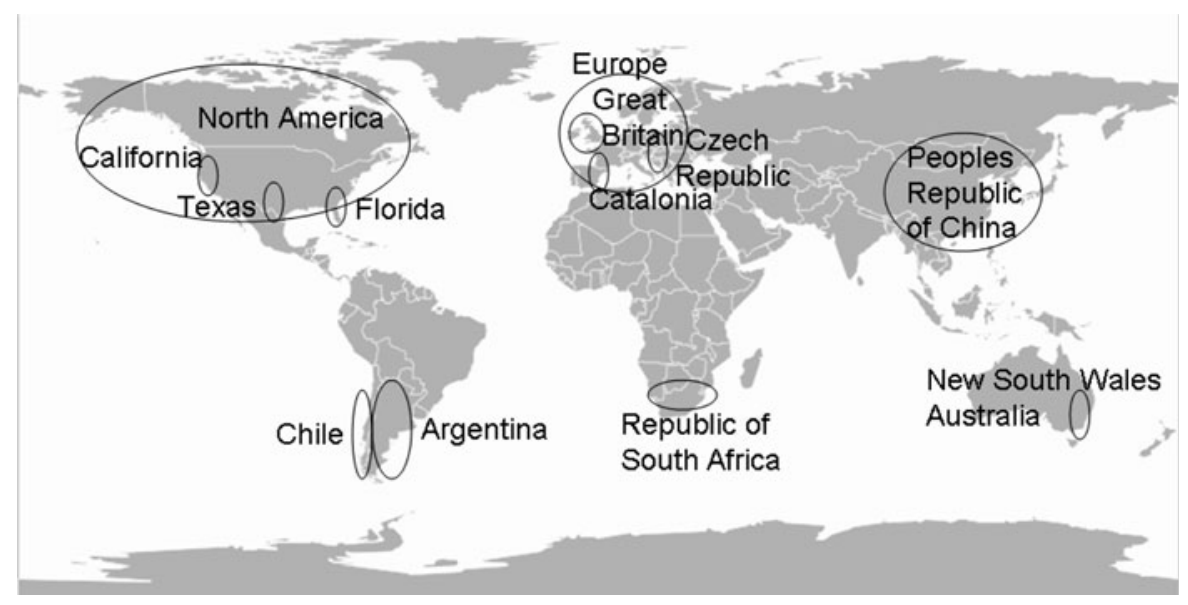

Fig. 1 Map of the general location of floras used in this study

Table 2 Percent of the 120 most widely distributed species represented by alien plant species

\begin{tabular}{lc}
\hline Regions & $\%$ Aliens \\
\hline North America & $51.3^{\mathrm{a}}$ \\
New South Wales & 43.3 \\
Chile & 34.2 \\
Argentina & 29.7 \\
Republic South Africa & 22.5 \\
China & 12.8 \\
Europe & 2.1 \\
Subregions in Europe & \\
Great Britain and Ireland & 3.3 \\
Catalonia, Spain & 8.3 \\
Czech Republic & 23.3 \\
Subregions in the United States & \\
California & 20.3 \\
Texas & 5.8 \\
Florida & 0.8 \\
\hline
\end{tabular}

a $40.1 \%$ among the 536 most distributed species

b The figure given is for the 536 most distributed species

The sample sites differed greatly in both area and species richness, so we conducted two additional tasks. First, we evaluated the top 120 species in three US states (California, Texas, and Florida), and in separate European regions (Great Britain and Ireland, the Czech Republic, and Catalonia in Spain) to see if patterns held at smaller spatial extents. Second, to be able to compare Europe with other regions of comparable size in our data set, we also evaluated the top 536 most widely distributed plant species in the conterminous United States, Republic of South Africa, and Europe to see if the patterns held at a larger geographical scale. In this case, the number of species analyzed was determined by a coarser resolution of European data; the threshold for the most distributed species in Europe was set as to capture the most widely distributed alien species that were species occurring in at least 20 of 23 subregions considered (regions for which complete lists both of alien and native species were collected; see Winter et al. 2009), and the number of species in North America and Republic of South Africa was adapted accordingly to make the three data sets comparable.

For the first sub-hypothesis, we simply compared the fraction of alien and native plant species on the lists of widely distributed plant species, because the regions were not randomly selected or totally independent in the statistical sense. For the second subhypothesis, we restricted quantitative and statistical tests to make a few obvious points. We used $t$ tests (with unequal variance) on log-transformed data to test for frequency differences within regions. Small sample sizes in some regions (e.g., aliens in Florida) prohibited tests. Also, for 11 independent regions, we regressed the percent alien species in a region with the difference in frequency distributions (i.e., percent of subregions occupied by alien species minus the percent of subregions occupied by native species), assuming that we had a representative and unbiased sample of regions around the globe (Fig. 1). 
Table 3 Comparison of widely distributed species in various regions and subregions around the world

\begin{tabular}{|c|c|c|}
\hline Regions Subregions & No. Species & Regions or Cells \\
\hline \multicolumn{3}{|c|}{ North America (119 species) } \\
\hline Alien & 61 & $64.0(0.3)_{\mathrm{a}}$ \\
\hline Native & 58 & $63.6(0.3)_{\mathrm{a}}$ \\
\hline \multicolumn{3}{|c|}{ North America (536 species) } \\
\hline Alien & 215 & $56.8(0.4)_{\mathrm{a}}$ \\
\hline Native & 320 & $55.0(0.3)_{\mathrm{b}}$ \\
\hline \multicolumn{3}{|c|}{ California (120 species) } \\
\hline Alien & 28 & $51.4(0.4)_{\mathrm{a}}$ \\
\hline Native & 110 & $51.9(0.2)_{\mathrm{a}}$ \\
\hline \multicolumn{3}{|l|}{ Texas (120 species) } \\
\hline Alien & 7 & $107.6(5.3)_{\mathrm{a}}$ \\
\hline Native & 113 & $111.5(1.7)_{\mathrm{a}}$ \\
\hline \multicolumn{3}{|l|}{ Florida (120 species) } \\
\hline Alien & 1 & $62.0(0.0)$ \\
\hline Native & 119 & $63.2(0.2)$ \\
\hline \multicolumn{3}{|c|}{ Argentina (118 species) } \\
\hline Alien & 35 & $18.4(0.5)_{\mathrm{a}}$ \\
\hline Native & 83 & $16.9(0.2)_{\mathrm{b}}$ \\
\hline \multicolumn{3}{|l|}{ Chile (120 species) } \\
\hline Alien & 42 & $10.6(0.3)_{\mathrm{a}}$ \\
\hline Native & 78 & $9.3(0.3)_{\mathrm{b}}$ \\
\hline \multicolumn{3}{|c|}{ South Africa (120 species) } \\
\hline Alien & 27 & $360.0(31.0)_{\mathrm{a}}$ \\
\hline Native & 93 & $240.0(8.8)_{\mathrm{b}}$ \\
\hline \multicolumn{3}{|c|}{ South Africa (536 species) } \\
\hline Alien & 52 & $255.3(21.7)_{\mathrm{a}}$ \\
\hline Native & 484 & $151.9(2.8)_{\mathrm{b}}$ \\
\hline \multicolumn{3}{|l|}{ Europe (536 species) } \\
\hline Alien & 11 & $20.4(0.4)_{\mathrm{a}}$ \\
\hline Native & 525 & $20.8(0.1)_{\mathrm{a}}$ \\
\hline \multicolumn{3}{|c|}{ Czech Republic (120 species) } \\
\hline Alien & 28 & $582.2(5.9)_{\mathrm{a}}$ \\
\hline Native & 92 & $596.7(4.2)_{\mathrm{a}}$ \\
\hline \multicolumn{3}{|c|}{ Great Britain and Ireland (120 species) } \\
\hline Alien & 4 & $3,310.8(73.9)_{\mathrm{a}}$ \\
\hline Native & 116 & $3,389.6(20.1)_{\mathrm{a}}$ \\
\hline \multicolumn{3}{|c|}{ Catalonia, Spain (120 species) } \\
\hline Alien & 10 & $250.4(9.4)_{\mathrm{a}}$ \\
\hline Native & 110 & $258.4(2.0)_{\mathrm{a}}$ \\
\hline \multicolumn{3}{|c|}{ New South Wales, Australia (120 species) } \\
\hline Alien & 52 & $12.7(0.1)_{\mathrm{a}}$ \\
\hline Native & 68 & $12.6(0.1)_{\mathrm{a}}$ \\
\hline
\end{tabular}

Table 3 continued

\begin{tabular}{lcc}
\hline Regions Subregions & No. Species & Regions or Cells \\
\hline China (109 species) & & \\
Alien & 14 & $5.2(0.9)_{\mathrm{a}}$ \\
Native & 95 & $3.9(0.4)_{\mathrm{a}}$ \\
\hline
\end{tabular}

Mean numbers of regions or cells occupied are followed by standard errors in parentheses. $T$ tests (unequal variance) were used to test for frequency differences within regions or subregions. Different subscripts denote significant differences in means within a region or subregion

We also arranged the 536 most widely distributed plant species in the conterminous United States, Republic of South Africa, and Europe by frequency in subregions to explore how the proportion of alien species changed with increasing number of species investigated.

\section{Results}

The fraction of widely distributed plant species that is alien is not similar among regions

The percentage of alien species represented in the 120 most widely distributed species varied greatly among regions (Table 2). In North America, over half of these species were from other continents, predominantly Europe $(\sim 85 \%)$, Eurasia $(\sim 7 \%)$ and Asia ( $\sim 3 \%)$. In Argentina and Chile, over $65 \%$ of the alien plant species that are widely spread are from Europe, with $\sim 9$ and $\sim 12 \%$, respectively, from Eurasia. Alien plant species were also well represented on the lists for New South Wales (43.3\%), Chile (34.2\%), Argentina (29.7\%), and the Republic of South Africa (22.5\%). Areas in Europe contained the fewest aliens on their lists, even though the alien plant species included neophytes and archaeophytes, and given Europe's long history of trade dating back two millennia or more (Table 2).

Individual subregions in Europe and North America varied considerably in the percentage of aliens on the 120 most widely distributed species lists (Table 1). In subregions, the percentage of aliens can be greater or less than that of the surrounding region. We found that California, with 5,688 total native plant species, had $20 \%$ aliens on the list, while Florida, with 3,284 total native plant species had $<1 \%$ aliens on the list (Table 2; Kartesz 2010). 

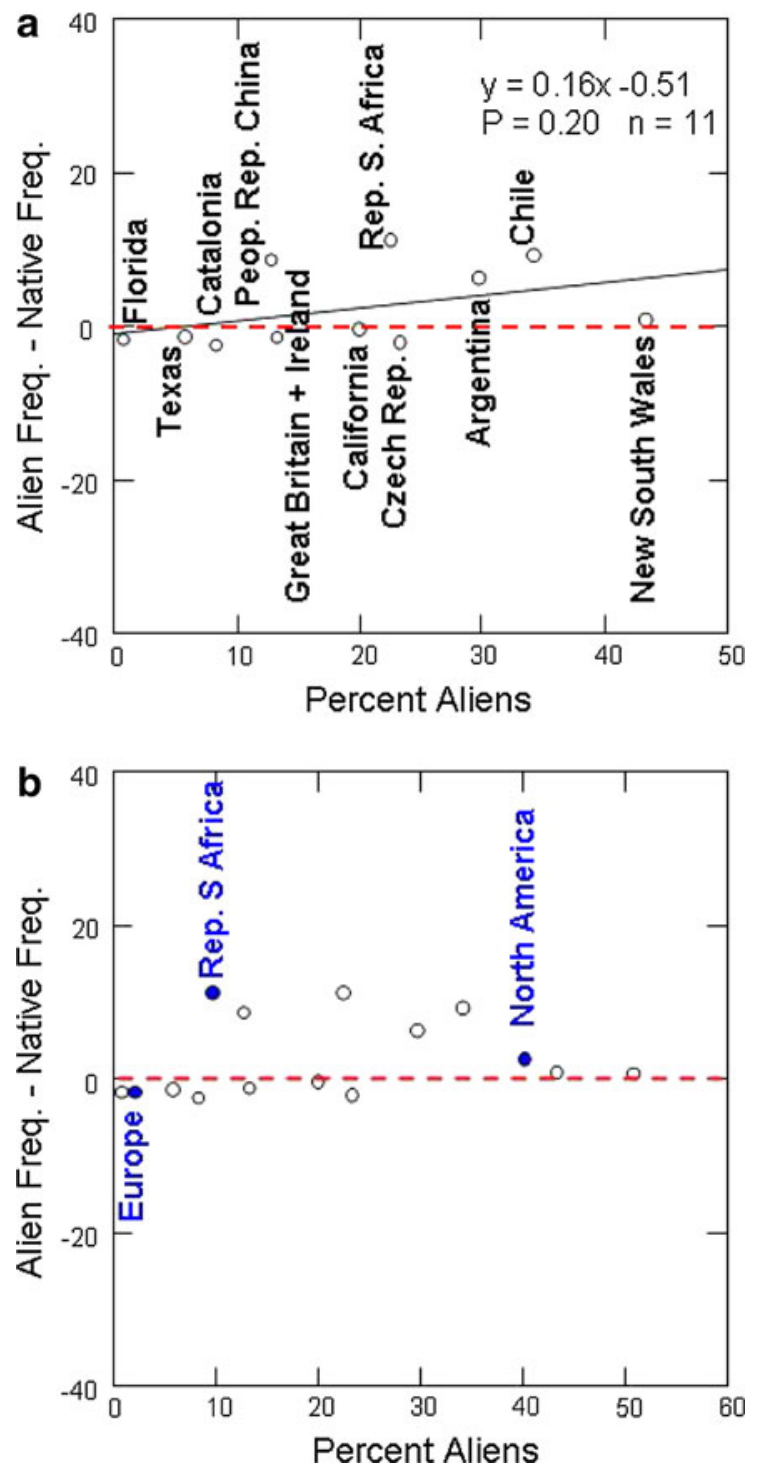

Fig. 2 Relationship of percent alien species in the 120 most widely distributed species in a region (from Table 1), and the difference in frequency of occurrences in sub-regions (from Table 2). Regions above zero on the $y$-axis denote that alien species are more widely distributed than native species

The alien plant species on regional/continental lists of the most widely distributed plant species are as widely if not more widely distributed as native plant species

The most surprising and consistent finding was that aliens often had equal or greater frequencies (in subregions) compared to native species in all areas examined and regardless of scale and extent of the study areas (Table 3). Aliens were significantly more widely distributed than most native plant species in North America (when 536 species were examined), Argentina, Chile, and the Republic of South Africa. Meanwhile, alien species were as widely distributed as native species in California, Texas, Florida, and throughout Europe (i.e., the frequencies were not statistically different). In general, aliens on the lists were as widely distributed as their native species counterparts (Table 3).

When we examined the relationship of percent alien species in the 120 most widely distributed species in a region (from Table 2), and the difference in frequency of occurrences in subregions (from Table 3), we found that many regions were above zero on the $y$-axis denoting that alien species were generally more widely distributed than their native species counterparts (Fig. 2a). However, the correlation of the two factors was not statistically significant $(P=0.21)$. When larger datasets and regions were included from North America, Europe, and the Republic of South Africa (Fig. 2b), there appeared to be less of correlation between the factors, but the data points are not independent, so the correlation was not tested.

When we arranged these 536 species in the conterminous United States, Republic of South Africa, and Europe by frequency in subregions, we found many of the alien species on the lists in North America and the Republic of South Africa were also the most widespread (Fig. 3). About $40 \%$ of these species in the United States were alien, while only $2.1 \%$ of them were alien to Europe. The Republic of South Africa had an intermediate pattern of invasion, with 16 alien species among the top 26 most widely distributed plant species. As more species were included in each of these large regions, native species began to dominate the lists in terms of cumulative proportion of species. However, the pattern in North America and South Africa suggest that "super-invaders" are among the top-most widely distributed species. Hence, we see the rapidly decreasing proportion of native species for the most widely distributed plant species (Fig. 3).

Widely distributed native or alien species around the globe do tend to come from particular plant families or groups

Many families overlap across continents such as Asteraceae, Brassicaceae, Poaceae, and Fabaceae (Appendix S1-Electronic Supplementary Material). 


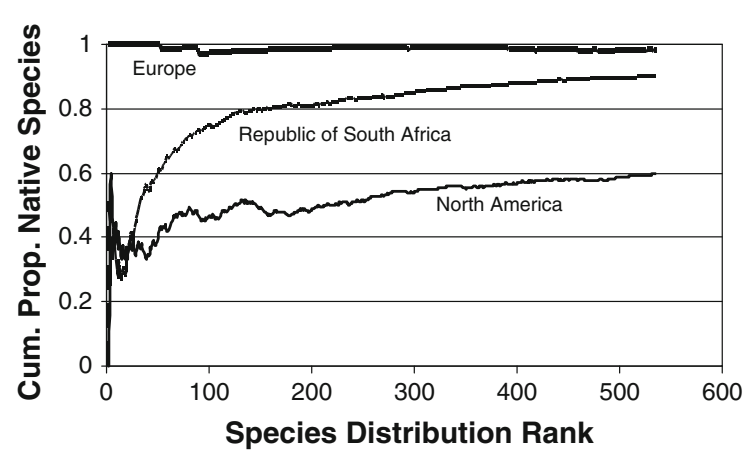

Fig. 3 Cumulative proportion of native species from the most widely distributed plant species to the 536th most widely distributed plant species in Europe, Republic of South Africa, and North America (north of Mexico). The data from the Republic of South Africa are a preliminary compilation of two datasets (aliens and natives in PRECIS (herbarium records) in the PRECIS dataset) and aliens only in the SAPIA dataset, which underestimates the number of sparsely distributed nonnatives relative to confirmed naturalized populations

Likewise, many families often overlap between native and alien species (or archaeotype species) within countries or regions (Appendix S1-Electronic Supplementary Material). The Poaceae and Asteraceae contain broadly spread native and alien species in North America, South Africa, and New South Wales. Asteraceae is widespread native and alien family in Great Britain and Ireland. Pinaceae and Salicaceae dominate preliminary lists of native and alien in China, but these lists are incomplete, especially for understory species.

There were too many species-level findings to report given this limited space, but a few examples are noteworthy. For example, Chenopodium album, a widely dispersed native species in Catalonia, Spain and the Czech Republic, is considered mostly exotic in North America, but with several native infraspecific taxa alien to Chile and New South Wales. Likewise, Cirsium vulgare, a native species in Great Britain and Ireland, and Catalonia, is a widely dispersed alien species in Chile, New South Wales, North America, and South Africa. In these cases, widely distributed native species became widely distributed alien species. The most widespread alien species in South Africa is Opuntia ficus-indica (L.) Mill. (Cactaceae), while in North America, it is Taraxacum officinale G.H. Weber ex Wiggers (Asteraceae).

Some species were more widely spread in their invaded habitat compared to their native homelands. Some species were more widely spread in their invaded habitat compared to their native homelands. Senecio vulgaris ranged broadly in Catalonia, and Great Britain and Ireland, but was less widespread in North America. Likewise, Agrostis stolonifera, native and widespread species in Great Britain and Ireland, was less so in Catalonia, and a significantly widespread alien weed in Chile. However, Bromus tectorum (cheat grass), a well known alien invader in North America, did not appear on any other lists. Likewise, Opuntia ficus-indica, the most widely distributed alien invader in South Africa, did not appear on the other lists, except in Argentina. Taraxacum officinale, the most widespread invasive in North America, is somewhat limited in its distribution in Asia.

\section{Discussion}

This study is the first collection of frequencies of alien and native species at almost a global scale (or with a global extent), producing a few salient patterns.

Patterns of invasion of widely distributed plant species are highly variable

We reject our sub-hypothesis that the fraction of the plant species that is alien is similar among regions. North America and Europe represent two ends of the spectrum (Table 2). Over half of the 120 most widely distributed species in North America were from other countries. In North America, about $40 \%$ of these plants appear on the lists from the other seven countries or regions. Meanwhile, native plant species comprise the vast majority of widely distributed plants species in Europe and its regions sampled. The species level analysis to date suggests Europe is a better donor than receptor of plant species (di Castri 1989; Pyšek 1998; Weber 2003; Winter et al. 2010), while North America proves to be a melting pot of both its flora, as well as its people; reflecting a highly correlated pattern of both types of immigrations over the past 500 years. However, every region on the globe must be considered a potential donor of alien species. Increased trade and transportation over the past five Centuries has drastically transformed the flora of North America. A new exhaustive phytogeographic assessment for all 36,000 North American plant taxa (species and infraspecific entities) occurring north of Mexico, reveals that $24 \%$ of the taxa 
occurring within the 72 major geopolitical subunits (US states and Canadian provinces) were introduced from other continents (Kartesz 2010). California, which had the highest native species diversity of any subunit, also had a high level of alien species.

Alien species, as a group in a region or country, tend to be as widely distributed as native species

We accept this primary sub-hypothesis. This is the first study to quantify that alien plant species tend to be as widely distributed as common native species (despite the disparity in the sizes of the areas evaluated, or in the proportion of alien species in different floras). This seems true despite widely different residence times for native and alien species in a region, and for different residence times of alien species among regions (e.g., Europe with North America). For many non-mutually exclusive reasons, plant species that continue to spread globally often have: (1) small seeds dispersed by wind and animals, (2) escaped from pathogens and herbivores, or (3) generalized habitat suitability (Pyšek and Richardson 2007). However, regardless of the proportion of alien species on the lists, alien have become widely distributed in their new countries or regions (Table 3; Fig. 2), probably for the same reasons. It has been recently shown that it takes on average about 150 years for an alien plant species in Europe to achieve a full distribution according to Williamson et al. (2009) and Gassó et al. (2010). Those authors also showed that, although many aliens are still in the process of extending their ranges, it may be assumed that some have made more progress than others.

Plant families associated with small seeds, food, forage, and hitchhiking dominate our lists of widely distributed native and alien species

The Asteraceae, Brassicaceae, Poaceae, and Fabaceae families are particularly widespread (Appendix S1Electronic Supplementary Material). These plant families and certain species within them are more common than others across the lists of widely distributed native or alien species around the globe. These families are large, so we might expect to see many invaders among them. Our finding also support those of Duncan and Williams (2002) in New Zealand, who found that species with congeneric relatives are significantly more, not less, likely to naturalize, because "they share with their native relatives traits that pre-adapt them to their new environment." Finding common invaders in many countries may aid in prevention and containment efforts. Obviously, effective prevention programs for harmful invasive species would benefit from tracking widely distributed alien and widely distributed native species around the globe (Pyšek et al. 2009).

The focus on trade and transportation

Our results clearly focus attention on the changing rate of globalization throughout history (Hopkins 2004). Since the dawn of trade-with the first traderoute arguably between the Sumer and Indus Valleys over 5,000 years ago (Frank 1998)—alien plants, animals, parasites, pathogens, and diseases were intentionally and accidentally exchanged (Comas et al. 1998). Globalization has more recently expanded in a stair-step fashion driven by specific technological innovations. For example, long-distance merchant ships in the Minoan, Greek, and Roman civilizations shortened the time to market for grain and other goods further connecting Europe, Africa, and Asia. Indeed by $67 \mathrm{BC}$, the vast Roman Empire had cargo ships designed to carry $70,000 \mathrm{~kg}$ of grain, food, and other supplies from far and wide (Kessler and Temin 2007), and many invasive plant species in Italy can be traced to these times (CelestiGrapow et al. 2009). Trade in crops accelerated in the Old World in the Islamic Golden Age (mid-eighth century to mid thirteenth century AD), when traders widely distributed sugar, cotton and other goods (Hobson 2004). Long before Marco Polo's explorations to China, peoples brought pasta wheat, sugar cane, spinach, and eggplant to the Mediterranean (Bober 2001). Likewise, in the New World, Native Americans were trading obsidian, shells, tobacco, maize, squash and dozens of other products (Wood 1972).

In the fifteenth to seventeenth century AD, the Age of Discovery (or Age of Exploration; or the Colombian Exchange) connected the Old World with the New World, thus greatly accelerating the exchange of agricultural products, precious metals, and even human cargo (di Castri 1989; Mack 2001). Food crops such as potatoes, tomatoes and maize, other agricultural crops (e.g., cotton, tobacco) and diseases 
(e.g. syphilis) moved from the New World to the Old World, while different crops (e.g. wheat and sugar cane), livestock (e.g. pigs, horses, cattle), pests and diseases (e.g. rats, plague, small pox, measles), and humans (e.g. slaves and settlers) were exchanged (Crosby 1972). In the late 18th century, the isolated southern-hemisphere continent of Australia was brought into somewhat permanent connection with the rest of the world when it was established by the British as a penal colony. Since then, a total of 26,242 alien plant species have been introduced into Australia (Randall 2007) from many different regions of the world (Groves and Hosking 1998; Cook and Dias 2006; Harris et al. 2007; Phillips et al. 2010a), with some notable periods of rapid exchange (e.g. between 1840 and 1880 as well as between 1980 and the present, Phillips et al. 2010b). More recently, but to a limited degree, even Antarctica has also been subject to globalization. In short, all the continents are essentially connected once again. For example, a MacDonald's Big Mac with fries and a coffee, contain plants from all eight global centers of cultivated plant diversity (Procheş et al. 2008).

The frequency of inter-change has increased similarly. International trade skyrocketed between 1870 and 1913. Growth of the global economy was directly related to shipping, where freight rates fell on average by $50 \%$, while global trade increased $400 \%$ (Jacks and Pendakur 2008). One analysis suggests that the combination of maritime and air cargo increased global trade roughly sixfold between 1950 and 2000 (Jacks et al. 2008). Another synthesis showed that after 1950, the volume of world merchandise increased 17-fold, while world Gross Domestic Product increased just sixfold (Flemming 2004). Thus, in the modern day, most of the goods consumed by humans stem from imports.

As the global economy expanded, so did trade in live organisms. Smith et al. (2009) synthesized trends that are alarming: billions of live animals and animal products are traded globally each year. These species have the potential to compete with native species for resources, alter ecosystems, damage infrastructure, and destroy crops. Likewise, the introduction of hitch-hiking pathogens and diseases threaten human health, agricultural production and biodiversity. The trade in live plant materials is equally alarming. In Great Britain, for example, about $27 \%$ of ornamental species on sale in nineteenth century were recorded growing outside cultivation (Smith et al. 2009). Ornamental horticulture is still a major pathway for plant introductions, and the dominant pathway for woody plant invaders (Reichard and White 2001; Hulme et al. 2008). The advent of e-commerce also makes the trade in live plants and seeds quicker and cheaper. For example, Maki and Galatowitsch (2004) found that prohibited alien aquatic plant species could easily be bought from plant vendors across the United States.

\section{Caveats and cautious generalizations}

There are several caveats to a study such as this one. We lack a probabilistic sampling design-our sites were subjectively selected (opportunistic sampling of available data from only eight countries or regions). The study sites varied in size from $9,596,960 \mathrm{~km}^{2}$ for the People's Republic of China to $20,600 \mathrm{~km}^{2}$ for Catalonia. Additionally, some study areas used political subregions, some used bioregions, and others use grid cells to determine frequency of occurrence. Therefore, the mean frequency values in Table 3 are exaggerated when data were collected by regions rather than smaller grid cells and they are not directly comparable across sites. The data we use reflect the availability of data on invasive plants globally, with still existing geographical bias due to which the quality of data across the globe varies, being generally poor in understudied continents (Pyšek et al. 2008). In some areas, there may be botanical bias against collecting alien species, and the density of botanists may have resulted in more complete datasets in some areas.

\section{Areas of future research}

We still do not know why some areas are more easily invaded than others (Richardson et al. 2005; Chytrý et al. 2008). General observations suggest that areas with high numbers of native species are vulnerable to invasions due to high resource availability and high environmental heterogeneity-and this pattern holds up generally well over large portions of the earth from local and regional scales (Stohlgren et al. 1999, 2003) to global scales (Lonsdale 1999). Increasing trade and transportation diminishes dispersal limitations, and increases the number of introductions and species overlap among regions 
and nations (Hulme et al. 2009; Pyšek et al. 2010). The number and overlap of alien taxa among countries or regions (Appendix S1-Electronic Supplementary Material) is a testament to trade and transportation. However, the paucity of widely distributed alien species in Europe and People's Republic of China remains an aberration. Very few of the 1,600 alien species, known to be introduced to Europe since $1500 \mathrm{AD}$, have become widespread; therefore, approximately 12,000 native plant species seem to be holding their ground (Winter et al. 2009). This is despite the fact alien species in Europe and China have been used intensively and extensively for agriculture, horticultural, silviculture, and for environmental engineering.

Climate, level of disturbance, time since introduction, and trade volume are often given as reasons for differences in invasion patterns. However, portions of the People's Republic of China, North America, and portions of Europe include temperate zones with very different invasion patterns. All these areas are heavily affected by land use change. The inclusion of archeophytes in Europe showed that as a group, they are equally distributed despite wildly different times since introduction (Pyšek et al. 2002, 2004b; Winter et al. 2010; but see La Sorte and Pyšek 2009). Increased volume of trade and transportation with People's Republic of China, a very species-rich country (Ricklefs 2005), may create additional challenges in other countries and regions. Europe, especially its Mediterranean region, has been traditionally considered a donor of invasive species to other parts of the world due to historical reasons and long association of plants and animals with humans since the beginning of agriculture some 10,000 years ago (di Castri 1989), which is reflected by the majority of invasive species on other continents being of Eurasian origin (Pyšek 1998; Weber 2003).

Regional and national plant inventories and databases are essential to understand patterns and impacts of invasions (Stohlgren et al. 2005; Cadotte et al. 2006; Crall et al. 2006; Lambdon et al. 2008b; Jarnevich and Stohlgren 2009, Vilà et al. et al. 2010). Yet in many cases, we are unable to determine the exact donor country or region of an alien species. In many cases, genetic research is needed to identify donor areas and to understand pathways of introductions. Such research is vital to developing effective prevention programs (Cox 2004).

\section{Conclusion}

Our data clearly show the changing origins of widely distributed plant species in several countries and regions worldwide. For most countries, over the past few hundred years, widely distributed species lists have gone from nearly all native species to a large percentage of alien species. Ricklefs (2005) proposed that: "On balance, regional comparisons of patterns of species richness suggest that large-scale processes (i.e., species formation) and unique historical and geographic circumstances have had a strong impact on patterns of plant diversity." While these processes may have determined the initial patterns of species richness around the globe, trade and transportation and changing patterns of widely distributed species may dominate future patterns of biodiversity. We may be witnessing accelerating effects of the great reshuffling of species on the globe (Mack 2001) as geographic isolation diminishes over time. Human assisted migrations, and unintentional species establishment followed by natural dispersal by wind, water, and animals may further spread alien species from local to global scales. While the scientific community is making great strides in tracking global invasive species (Simpson et al. 2009), it might be prudent to begin thinking about the tracking on widely distributed native species as likely donor populations.

Acknowledgments We thank the many taxonomists and database providers that made this study possible. Lifetimes of taxonomist expertise were required for geographic completeness, taxonomic accuracy, and quality control required for this cursory analysis. To taxonomists and data managers everywhere, we are grateful. We thank Zuzana Sixtová for technical assistance. PP was supported by the Academy of Sciences of the Czech Republic (AV0Z60050516 and Praemium Academiae Award) and the Ministry of Education of the Czech Republic (MSM0021620828 and LC06073). AP contribution supported by ICM P05-002 and PFB-23. TJS contribution supported by U.S. Geological Survey Invasive Species Program, USGS Fort Collins Science Program, and USDA CSREES/NRI 2008-35615-04666. We thank C. Daehler and two anonymous reviewers for very helpful suggestions.

\section{References}

Bober PP (2001) Art, culture, and cuisine: ancient and medieval gastronomy. University of Chicago Press, Chicago

Cadotte MW, Murray BR, Lovett-doust J (2006) Ecological patterns and biological invasions using regional species inventories in macroecology. Biol Invasions 8:809-821 
Cassey P, Blackburn TM, Lockwood JL, Sax DF (2006) A stochastic model for integrating changes in species richness and community similarity across spatial scales. Oikos 115:207-218

Castro SA, Jaksic FM (2008) How general are global trends in biotic homogenization? Floristic tracking in Chile, South America. Glob Ecol Biogeogr 17:524-531

Celesti-Grapow L, Alessandrini A, Arrigoni PV, Banfi E, Bernardo L, Bovio M, Brundu G, Cagiotti MR, Camarda I, Carli E, Conti F, Fascetti S, Galasso G, Gubellini L, La Valva V, Lucchese F, Marchiori S, Mazzola P, Peccenini S, Poldini L, Pretto F, Prosser F, Siniscalco C, Villani MC, Viegi L, Wilhalm T, Blasi C (2009) Inventory of the non-native flora of Italy. Plant Biosyst 143:386-430

Chytrý M, Maskell LC, Pino J, Pyšek P, Vilà M, Font X, Smart SM (2008) Habitat invasions by alien plants: a quantitative comparison among Mediterranean, subcontinental and oceanic regions of Europe. J Appl Ecol 45:448-458

Comas DF, Calafell E, Mateu E, Perez-Lezaun A, Bosch E, Martinez-Arias R, Clarimon J, Facchini F, Fiori G, Luiselli D, Pettener D, Bertranpetit J (1998) Trading genes along the Silk Road: mtDNA sequences and the origin of Central Asian populations. Am J Hum Genet 63: $1824-1838$

Condie KC (1989) Plate tectonics and crustal evolution, 3rd edn. Pergamon Press, Oxford

Cook GD, Dias L (2006) It was no accident: deliberate plant introductions by Australian government agencies during the 20th century. Aust J Bot 54:601-625

Cox GW (2004) Alien species and evolution. Island Press, Washington, DC, pp 40-42

Crall AW, Meyerson LA, Stohlgren TJ, Jarnevich CS, Newman GJ, Graham JJ (2006) Show me the numbers: what data currently exist for non-native species in the USA? Front Ecol Environ 4:414-418

Crosby AW (1972) The Columbian exchange: biological and cultural consequences of 1492. Greenwood Publishing Group, Connecticut

DAISIE (2009) Handbook of alien species in Europe. Springer, Berlin

Davis MA (2003) Biotic globalization: does competition from introduced species threaten biodiversity? Bioscience 53:481-489

di Castri F (1989) History of biological invasions with special emphasis on the Old World. In: Drake JA, Mooney HA, di Castri F, Groves RH, Kruger FJ, Rejmánek M, Williamson $\mathrm{M}$ (eds) Biological invasions: a global perspective. Wiley, Chichester, pp 1-30

Duncan RP, Williams PA (2002) Ecology: Darwin's naturalization hypothesis challenged. Nature 417:608-609

Flemming L (2004) Excel HSC business studies. Pascal Press, Glebe

Frank AG (1998) Reorient: global economy in the Asian Age. U.C. Berkeley Press, Berkeley

Gassó N, Pyšek P, Vilà M, Williamson M (2010) Spreading to a limit: the time required for a neophyte to reach its maximum range. Divers Distrib 16:310-311

Germishuizen G, Meyer NL (2003) Plants of Southern Africa: an annotated checklist. Strelitzia 14:1-1231

Groves RH, Hosking JR (1998) Recent incursions of weeds to Australia 1971-1995. Cooperative Research Centre for
Weed Management Systems, Technical Series No. 3, Adelaide

Harris CJ, Murray BR, Hose GC, Hamilton MA (2007) Introduction history and invasion success in exotic vines introduced to Australia. Diversity Distrib 13:467-475

Henderson L (1998) Southern African Plant Invaders Atlas (SAPIA). Appl Plant Sci 12:31-32

Hobson JM (2004) The eastern origins of western civilisation. Cambridge University Press, Cambridge

Hopkins AG (ed) (2004) Globalization in world history. Norton, New York

Hulme PE, Bacher S, Kenis M, Klotz S, Kühn I, Minchin D, Nentwig W, Olenin S, Panov V, Pergl J, Pyšek P, Roques A, Sol D, Solarz W, Vilà M (2008) Grasping at the routes of biological invasions: a framework for integrating pathways into policy. J Appl Ecol 45:403-414

Hulme PE, Pyšek P, Nentwig W, Vilà M (2009) Will threat of biological invasions unite the European Union? Science 324:40-41

Jablonski D (1989) The biology of mass extinction: a palaeontological view. Philos Trans R Soc Lond B 325: 357-368

Jacks D, Pendakur K (2008) Global trade and the maritime transport revolution. National Bureau of Economic Research Working Paper No. 14139

Jacks D, Meissner C, Novy D (2008) Trade costs, 1870-2000. Am Econ Rev Pap Proc 98(2):529-534

Jäger EJ (1988) Möglichkeiten der Prognose synanthroper Pflanzenausbreitungen. Flora 180:101-131

Jarnevich CS, Stohlgren TJ (2009) Near term climate projections for invasive species distributions. Biol Invasions 11:1373-1379

Kartesz JT (2010) Floristic synthesis of North America. Biota of North America Program. (www.BONAP.org)

Kessler D, Temin P (2007) The organization of the grain trade in the early Roman Empire. Econ Hist Rev 60:313-332

Kueffer C, Daehler CC, Torres-Santana CW, Lavergne C, Meyer JY, Otto R, Silva L (2010) A global comparison of plant invasions on oceanic islands. Perspect Plant Ecol Evol Syst 12:145-161

La Sorte FA, Boecklen WJ (2005) Changes in the diversity structure of avian assemblages in North America. Glob Ecol Biogeogr 14:367-378

La Sorte FA, Pyšek P (2009) Extra-regional residence time as a correlate of plant invasiveness: European archaeophytes in the North American flora. Ecology 90:2589-2597

La Sorte FA, McKinney ML, Pyšek P (2007) Compositional similarity among urban floras within and across continents: Biogeographical consequences of human-mediated biotic interchange. Glob Change Biol 13:913-921

Lambdon PW, Lloret F, Hulme PE (2008a) Do non-native species invasions lead to biotic homogenization at small scales? The similarity and functional diversity of habitats compared for alien and native components of Mediterranean floras. Divers Distrib 14:774-785

Lambdon PW, Pyšek P, Basnou C, Hejda M, Arianoutsou M, Essl F, Jarošík V, Pergl J, Winter M, Anastasiu P, Andriopoulos P, Bazos I, Brundu G, Celesti-Grapow L, Chassot P, Delipetrou P, Josefsson M, Kark S, Klotz S, Kokkoris Y, Kühn I, Marchante $\mathrm{H}$, Perglová I, Pino J, Vilà M, Zikos A, Roy DB, Hulme PE (2008b) Alien flora of 
Europe: species diversity, temporal trends, geographical patterns and research needs. Preslia 80:101-149

Leprieur F, Beauchard O, Hugueny B et al (2008) Null model of biotic homogenization: a test with the European freshwater fish fauna. Divers Distrib 14:291-300

Lonsdale WM (1999) Global patterns of plant invasions and the concept of invasibility. Ecology 80:1522-1536

Mack RN (2001) Motivations and consequences of the human dispersal of plants. In: McNeely JA (ed) The great reshuffling: human dimensions in invasive alien species. International Union for the Conservation of Nature, Gland, pp 23-34

Maki K, Galatowitsch S (2004) Movement of invasive aquatic plants into Minnesota (USA) through horticultural trade. Biol Conserv 118:389-396

McKinney ML, La Sorte FA (2007) Invasiveness and homogenization: synergism of wide dispersal and high local abundance. Glob Ecol Biogeogr 16:394-400

McKinney ML, Lockwood JL (1999) Biotic homogenization: a few winners replacing many losers in the next mass extinction. Trends Ecol Evol 14:450-453

McKinney ML, Lockwood JL (2001) Biotic homogenization: a sequential and selective process. In: Lockwood JL, McKinney ML (eds) Biotic homogenization. Kluwer/Plenum, New York, pp 1-18

McKinney ML, Lockwood JL (2005) Community composition and homogenization-evenness and abundance of native and exotic plant species. In: Sax DF, Stachowicz JJ, Gaines SD (eds) Species invasions-insight into ecology, evolution and biogeography. Sinauer Associates, Inc. Publishers, Sunderland, pp 365-380

Olden JD, Poff NL (2003) Toward a mechanistic understanding and prediction of biotic homogenization. Am Nat 162:442-460

Olden JD, Rooney TP (2006) On defining and quantifying biotic homogenization. Glob Ecol Biogeogr 15:113-120

Peterson AT (2001) Predicting species' geographic distributions based on ecological niche modeling. Condor 103: 599-605

Phillips ML, Murray BR, Leishman MR, Ingram R (2010a) The naturalization to invasion transition: are there introduction-history correlates of invasiveness in exotic plants of Australia? Austral Ecol 35:695-703

Phillips ML, Murray BR, Pyšek P, Pergl J, Jarošík V, Chytrý M, Kühn I (2010b) Plant species of the Central European flora as aliens in Australia. Preslia 82:465-482

Pino J, Font X, de Cáceres M, Molowny R (2009) Floristic homogenization by native ruderal and alien plants in north-east Spain: the effect of environmental differences on a regional scale. Glob Ecol Biogeogr 18:563-574

Preston CD, Pearman DA, Dines TD (2002) New atlas of the British and Irish flora. Oxford University Press, Oxford

Procheş Ş, Wilson JRU, Vamosi JC, Richardson DM (2008) Plant diversity in the human diet: weak phylogenetic signal indicates breadth. Bioscience 58:151-159

Pyšek P (1998) Is there a taxonomic pattern to plant invasions? Oikos 82:282-294

Pyšek P, Richardson DM (2007) Traits associated with invasiveness in alien plants: where do we stand? In: Nentwig W (ed) Biological invasions. Springer, Berlin, pp 97-126
Pyšek P, Sádlo J, Mandák B (2002) Catalogue of alien plants of the Czech Republic. Preslia 74:97-186

Pyšek P, Richardson DM, Rejmánek M, Webster G, Williamson M, Kirschner J (2004a) Alien plants in checklists and floras: towards better communication between taxonomists and ecologists. Taxon 53:131-143

Pyšek P, Richardson DM, Williamson M (2004b) Predicting and explaining plant invasions through analysis of source area floras: some critical considerations. Divers Distrib 10:179-187

Pyšek P, Richardson DM, Pergl J, Jarošík V, Sixtová Z, Weber E (2008) Geographical and taxonomic biases in invasion ecology. Trends Ecol Evol 23:237-244

Pyšek P, Jarošík V, Pergl J, Randall R, Chytrý M, Kühn I, Tichý L, Danihelka J, Chrtek JJ, Sádlo J (2009) The global invasion success of Central European plants is related to distribution characteristics in their native range and species traits. Divers Distrib 15:891-903

Pyšek P, Jarošík V, Hulme PE, Kühn I, Wild J, Arianoutsou M, Bacher S, Chiron F, Didžiulis V, Essl F, Genovesi P, Gherardi F, Hejda M, Kark S, Lambdon PW, DesprezLoustau A-M, Nentwig W, Pergl J, Poboljšaj K, Rabitsch W, Roques A, Roy DB, Solarz W, Vilà M, Winter M (2010) Disentangling the role of environmental and human pressures on biological invasions. Proc Natl Acad Sci USA 107:12157-12162

Qian H, Ricklefs RE (2006) The role of exotic species in homogenizing the North American flora. Ecol Lett 9: 1293-1298

Randall RP (2007) The introduced flora of Australia and its weed status. CRC for Australian Weed Management, Department of Agriculture and Food, Western Australia \& University of South Australia, Adelaide

Reichard SH, White P (2001) Horticulture as a pathway of invasive plant introductions in the United States. Bioscience 51:103-113

Rejmánek M (2000) A must for North American biogeographers. Divers Distrib 6:208-211

Richardson DM, Pyšek P, Rejmánek M, Barbour MG, Panetta FD, West CJ (2000) Naturalization and invasion of alien plants: concepts and definitions. Divers Distrib 6:93-107

Richardson DM, Rouget M, Ralston SJ, Cowling RM, Van Rensburg BJ, Thuiller W (2005) Species richness of alien plants in South Africa: environmental correlates and the relationship with indigenous plant species richness. Ecoscience 12:391-402

Ricklefs RE (2005) Historical and ecological dimensions of global patterns in plant diversity. Biologiske Skrifter 55:583-603

Rooney TP, Wiegmann SM, Rogers DA et al (2004) Biotic impoverishment and homogenization in unfragmented forest understory communities. Conserv Biol 18:787-798

Sax DF, Gaines SD, Brown JH (2002) Species invasions exceed extinctions on islands worldwide: a comparative study of plants and birds. Am Nat 160:766-783

Schönfelder P (1999) Mapping the flora of Germany. Acta Botanica Fennica 162:43-53

Simpson A, Jarnevich C, Madsen J, Westbrooks R, Fournier C, Mehrhoff L, Browne M, Graham J, Sellers E (2009) Invasive species information networks: collaboration at 
multiple scales for prevention, early detection, and rapid response to invasive alien species. Biodiversity 10:5-13

Smith KF, Behrens M, Schloegel LM, Marano N, Burgiel S, Daszak P (2009) Reducing the risks of the wildlife trade. Science 324:594-595

Stohlgren TJ (2007) Measuring plant diversity: lessons from the field. Oxford University Press, New York

Stohlgren TJ, Binkley D, Chong GW, Kalkhan MA, Schell LD, Bull KA, Otsuki Y, Newman G, Bashkin M, Son Y (1999) Exotic plant species invade hot spots of native plant diversity. Ecol Monogr 69:25-46

Stohlgren TJ, Barnett D, Kartesz J (2003) The rich get richer: patterns of plant invasions in the United States. Front Ecol Environ 1:11-14

Stohlgren TJ, Barnett D, Flather C, Kartesz J, Peterjohn B (2005) Plant species invasions along the latitudinal gradient in the United States. Ecology 86:2298-2309

Stohlgren TJ, Barnett DT, Jarnevich CS, Flather C, Kartesz J (2008) The myth of plant species saturation. Ecol Lett 11:313-326

Thompson K, Hodgson JG, Rich TCG (1995) Native and alien invasive plants: more of the same? Ecography 18:390-402

Van Turnhout CAM, Foppen RPB, Leuven R et al (2007) Scale-dependent homogenization: changes in breeding bird diversity in The Netherlands over a 25 -year period. Biol Conserv 134:505-516

Vilà M, Basnou C, Pyšek P, Josefsson M, Genovesi P, Gollasch S, Nentwig W, Olenin S, Roques A, Roy D, Hulme PE, DAISIE partners (2010) How well do we understand the impacts of alien species on ecological services? A panEuropean cross-taxa assessment. Front Ecol Environ 8:135-144

Weber E (2003) Invasive plant species of the world: a reference guide to environmental weeds. $\mathrm{CAB}$ International Publishing, Wallingford

Whinam J, Chilcottb N, Bergstromb DM (2005) Subantarctic hitchhikers: expeditioners as vectors for the introduction of alien organisms. Biol Conserv 121:207-219

Williamson M, Dehnen-Schmutz K, Kühn I, Hill M, Klotz S, Milbau A, Stout J, Pyšek P (2009) The distribution of range sizes of native and alien plants in four European countries and the effects of residence time. Divers Distrib 15:158-166

Wilson JRU, Richardson DM, Rouget M, Procheş Ş, Amis MA, Henderson L, Thuiller W (2007) Residence time and potential range: crucial considerations in modelling plant invasions. Divers Distrib 13:11-22

Wilson JRU, Dormontt EE, Prentis PJ, Lowe AJ, Richardson DM (2009) Something in the way you move: dispersal pathways affect invasion success. Trends Ecol Evol 24:136-144

Winter M, Kühn I, Nentwig W, Klotz S (2008) Spatial aspects of trait homogenization within the German flora. J Biogeogr 35:2289-2297

Winter M, Schweiger O, Klotz S, Nentwig W, Andriopoulos P, Arianoutsou M, Basnou C, Delipetrou P, Didžiulis V, Hejda M, Hulme PE, Lambdon PW, Pergl J, Pyšek P, Roy DB, Kühn I (2009) Plant extinctions and introductions lead to phylogenetic and taxonomic homogenization of the European flora. Proc Natl Acad Sci USA 106:21721-21725

Winter M, Kühn I, La Sorte FA, Schweiger O, Nentwig W, Klotz S (2010) The role of non-native plants and vertebrates in defining patterns of compositional dissimilarity within and across continents. Glob Ecol Biogeogr 19:332-342

Wood WR (1972) Contrastive features of Native North American trade systems. In: Voget FW, Stephenson RL (eds) For the chief: essays in honor of Luther S. Cressman. University of Oregon Anthropological Papers No. 4, Eugene, OR, pp 164-165

Zhengyi W (2003) Flora of China. In: Zhengyi W, Raven PH (eds) P. R. China, and Missouri Botanical Garden Press, St. Louis

Zuloaga FO, Morrone O (eds) (1996) Catálogo de las plantas vasculares de la República Argentina. I. Pteridophyta, Gymnospermae y Angiospermae (Monocotyledonae), II. Dicotyledonae. Monogr Syst Bot, Missouri Botanical Garden 60:1-79. http://www.darwin.edu.ar/Publicaciones/ CatalogoVascII/CatalogoVascII.asp 